\title{
Temporal variation in pond use and breeding success for ducks in French fishpond regions: on possible consequences of a decline in fish farming
}

\author{
J. Broyer ${ }^{(1), \star}$, F. Bourguemestre ${ }^{(2)}$, G. Chavas ${ }^{(3)}$, R. Chazal ${ }^{(1)}$ \\ Received March 31, 2015 \\ Revised October 13, 2015 \\ Accepted October 14, 2015
}

Key-words: fish farming decline, fishpond, duck population, habitat use, carrying capacity

\section{ABSTRACT}

Fish farming abandonment or extensification may theoretically lead to contrasting consequences for waterfowl breeding in fishpond complexes. We investigated the variation of four indices of duck density or breeding success in pond samples of three main French fishpond areas: Dombes, Forez and Brenne, along with recent changes in fish farming management. In Forez, where fish stocking has been frequently interrupted or fish biomass in ponds has substantially decreased during the two last decades, duck pair density strongly increased in the same time interval, but Mallard Anas platyrhynchos brood size decreased. In Brenne, no fish farming abandonment was observed but pond fertilization with organic manure or mineral nitrogen became less frequently implemented during the 2000s. The duck brood: pair ratio decreased meanwhile, indicating either a lower nesting success or higher losses before or immediately after hatching. In Dombes, lower fish stock densities since the 1990s did not reverse a negative trend in duck populations which started in the early 1980s. Our results suggest that fish biomass density in fishponds might be a limiting factor for breeding waterfowl, but a decrease in the nutrient level, for example with lower fertilizer inputs, may negatively affect duck reproductive success.

\section{RÉSUMÉ}

Variation temporelle de l'utilisation des étangs et succès de reproduction des canards dans les régions françaises d'étangs piscicoles : sur les conséquences possibles d'un déclin de la pisciculture

\author{
Mots-clés: \\ déclin de la \\ pisciculture, \\ étang aquacole, \\ population de \\ canard, \\ utilisation de \\ l'habitat, \\ capacité \\ d'accueil
}

L'abandon ou l'extensification de la pisciculture dans les régions d'étangs peut théoriquement s'accompagner de conséquences diverses pour l'avifaune aquatique. Nous avons étudié l'évolution de quatre indices décrivant la densité et les résultats de la reproduction des Anatidés sur des échantillons d'étangs de la Dombes, du Forez et de la Brenne, simultanément à une évolution des pratiques piscicoles. Dans le Forez, où de plus en plus d'étangs ne sont plus régulièrement empoissonnés et où la biomasse piscicole a fortement diminué au cours des deux dernières décennies, la densité des couples de canards a nettement augmenté,

(1) Office National de la Chasse et de la Faune Sauvage (ONCFS), Direction de la Recherche et de l'Expertise, Station de la Dombes, Montfort, 01330 Birieux, France

(2) Fédération des Chasseurs de I'Indre, BP 12, 46 Bd du Moulin Neuf, 36001 Châteauroux Cédex, France

(3) Fédération des Chasseurs de la Loire, Impasse Saint Exupéry, 42160 Andrézieux-Bouthéon, France 
mais la taille des nichées de colvert a diminué. En Brenne, la fertilisation des étangs a été souvent abandonnée après 2000. Dans le même temps, le rapport du nombre de nichées sur celui des couples a diminué, ce qui peut refléter soit une moindre fertilité des couples, soit des pertes plus importantes de nichées avant ou peu après l'éclosion. En Dombes, une réduction de la biomasse piscicole depuis les années 1990 n'a apparemment pas permis d'inverser une tendance démographique très négative amorcée depuis les années 1980. Dans l'ensemble, ces observations confortent l'hypothèse selon laquelle la gestion piscicole est une variable très influente sur la reproduction des Anatidés dans les régions d'étangs, avec notamment un effet limitant de la biomasse piscicole, mais aussi de l'état trophique qui gouverne la productivité de l'écosystème.

\section{INTRODUCTION}

Fishpond regions are major breeding areas for waterfowl in Europe. In this anthropogenic ecosystem, fish farming is one of the predominant factors likely to influence waterfowl pond use and demography. Carp Cyprinus carpio, which is generally predominant in European fishponds, may feed on invertebrates and could thereby compete with ducks. Grazing by carps might also affect duck habitat through its impact on water transparency and on the development of macrophytes (Lilie and Evrard, 1994; Bouffard and Hanson, 1997; Pokorny and Pechar, 2000). Intensification and high fish biomass may therefore negatively affect duck breeding (Meijer et al., 1990; Haas et al., 2007; Broyer and Calenge, 2010). There is however evidence that waterfowl reproduction may also benefit from fish farming management, for example when the trophic capacity of the aquatic ecosystem is artificially elevated through pond fertilization or extra food provided to fish (Kozulin et al., 2002; Broyer and Curtet, 2010). The rise and fall of diving duck populations in Czech ponds across the XXth Century could be a possible illustration of these paradoxical effects of fish farming management (Pykal and Janda, 1994; Albrecht et al., 2000). Fish farming abandonment or extensification may then theoretically be either beneficial or detrimental to pond attractiveness for waterfowl, and possibly to duck demography. In France, fish farming in the main fishpond regions is undergoing chronic economic difficulties, resulting in a growing trend toward fish stocking abandonment or decreasing investment in fish production (Bobbe, 2010). The total production of French fishpond regions decreased from 10506 tons in 2000 to 8000 in 2010 (Agreste, 2010). Such large scale changes probably lead to significant variations in pond carrying capacity, potentially affecting pond use by waterfowl and population productivity. Ducks are important contributors to biodiversity in European wetlands. They are also popular game birds. Understanding the consequences of the ongoing habitat changes in fishpond complexes is therefore a crucial challenge for a wise hunting management.

In this study, we monitored annually duck pond use and demographic indices in three fishpond regions diversely affected by a decline in fish farming and attempted to confirm, at the scale of regional pond samples, the hypotheses of a positive effect of decreasing fish biomass and negative consequences of decreased fertilizer inputs by fish farmers, on four variables describing pond attractiveness and carrying capacity for ducks: pair density, brood: pair ratio, brood size and duckling loss in the early stage of growth.

\section{METHODS}

\section{> STUDY REGIONS}

The study was carried out in fishpond regions which are important for duck breeding in France: Brenne (1999-2012) in central France, Dombes (1994-2012) and Forez (1992-2012)

\footnotetext{
${ }^{\star}$ Corresponding author: joel.broyer@oncfs.gouv.fr
} 


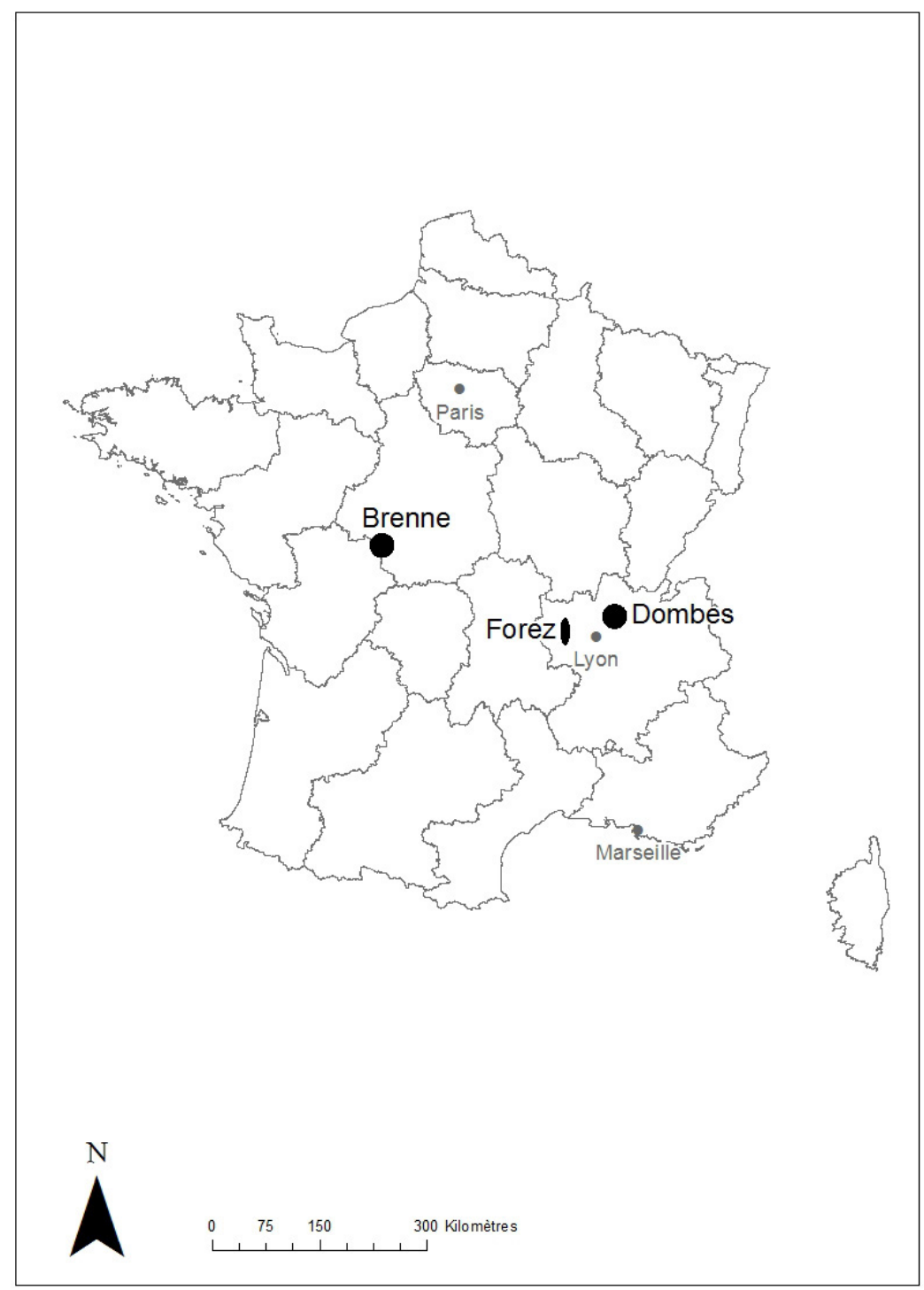

Figure 1

Location of the study regions.

in the east, where fish farming is similarly based on the production of Carp (Figure 1). Recent fish farming extensification or interruption in these study regions may have theoretically affected pond carrying capacity for waterfowl by decreasing the competition with fish for macro-invertebrates or the impact of high carp biomass on aquatic plants (Crivelli, 1983). In each region, pond surroundings are made up mainly by croplands or grasslands, more intensively managed in Dombes where a massive conversion of grasslands to cereal crops since the 1970s had severely affected duck breeding conditions (Tournier, 1990; Broyer, 2000). This reduction in meadow habitats in Dombes may have led to nest concentration in aquatic vegetation and increased impacts of nest predators (Broyer, 2009). The game harvest at the opening of the hunting season probably impinges on local production. No statistics are available but the hunting pressure in the study regions may be considered as stable or slightly decreasing. A striking change in the aquatic ecosystem however is the rapid expansion of the Coypu Myocastor coypus in the three regions studied with probable negative consequences on aquatic vegetation and thereby on nest site availability (Curtet et al., 2008).

Pochard Aythya ferina and Mallard Anas platyrhynchos are the most abundant breeding species in the three regions, with varying populations of Gadwall Anas strepera, Tufted Duck 
Aythya fuligula, Red-crested Pochard Netta rufina, and Garganey Anas querquedula, Common Teal Anas crecca, Shoveler Anas clypeata as rare breeders. The study regions differ by their respective pond numbers: $>1000$ in Dombes and in Brenne, 250 in Forez.

\section{> POND SAMPLING}

Duck breeding was studied in regional samples of 80 ponds in Dombes (surface area $S=$ $13.9 \pm 13.3 \mathrm{ha}), 57$ in Brenne $(S=10.9 \pm 9.1 \mathrm{ha})$ and 60 in Forez $(S=7.4 \pm 7.6$ ha). Samples were stable from year to year except in Dombes where a partial turnover enabled us to take into account a systematic one-year period of pond drying-out every 3 or 4 years. Available roads or lanes suitable for motor vehicles were used as transects from which all successive accessible ponds were included in the regional samples. In each region, five transects were set up, likely to be accomplished each within a day. They were planned so as to cross the most representative parts of the study regions and to enable the inclusion in samples of typically managed fishponds. The distances to reach all studied ponds of each transect were 5-8 km, covered by car. Distances between neighbouring transects were 3-5 km.

\section{> EVOLUTION IN FISH FARMING}

In Forez, fish farming was traditionally productive $\left(400 \mathrm{~kg} \cdot \mathrm{ha}^{-1}\right)$. Usually, ponds are not fertilized and no extra food is provided to fish, but large amounts of phosphoric industrial residues have been added to the sediments from the 1930s to the 1980s to increase plankton biomass (Robin, 1999). The overall fish production in Forez decreased from 675 tons in the early 1990s, to 487 in 1999, 271 in 2007 and 120 in 2010 (ADAPRA, 2011). The managers of the ponds that were selected for this study were interviewed in 1998 and in 2014. In this region, we expected that local duck populations would have benefited from a decreasing competition with fish.

In Brenne, fish-farming management was similarly described through two successive investigations, in 1999-2000 and in 2013, by querying fish-farmers of the ponds sampled for this study. In the period 1999-2001, pond fertilization in Brenne (about $500 \mathrm{~kg} \cdot \mathrm{ha}^{-1}$ of organic manure and/or 20-35 kg.ha-1 of mineral nitrogen) was related to: (1) higher biomass density of invertebrate-prey in aquatic macrophyte beds, as a probable effect of fertilizer on plankton populations, (2) higher duck brood density, despite higher fish biomass (Broyer and Curtet, 2011a). Fertilizer inputs and correlatively enhanced food resources should therefore have been theoretically favourable to duck breeding in this region despite competition with fish.

In Dombes, data provided by the main cooperative of producers indicated that pond productivity decreased on average from $250 \mathrm{~kg} \cdot \mathrm{ha}^{-1}$ in 1990 to 170 in 2010 , so that total production in Dombes decreased from 865 tons of carps at the end of the 1990 s to 600 tons in 2013 (Conseil Général de l'Ain, 2013). By interviewing the managers of 209 fishponds in 2006, we found that at least $66.0 \%$ were never fertilized (unpubl. data). Analyzing the relationships between changes in fish farming and waterfowl breeding is more difficult in this region because duck populations have been depressed after the development of intensive cereal crops in pond surroundings since the 1970s (Broyer, 2000). We only attempted to verify whether an overall lower fish biomass density in ponds could reverse the long term negative trend in duck demography. In Dombes, no specific investigation was carried out on the management of study ponds. These ponds were selected so as to include only typically managed water bodies. The observed trend in the sample may therefore be considered as representative of the general trend.

\section{> DUCK CENSUS}

Duck adults and broods were censused every week from mid-April to the end of July, by one unique comprehensive, very slow, scanning of all pond areas with a telescope $\times 40$. Observations were limited to mornings and late afternoons so as to avoid the hottest daily period 
when birds may search shelter within vegetation cover. The time spent on each pond was proportional to the surface area to be surveyed (scan length) and to the abundance of aquatic vegetation likely to constitute visual obstacles (scan slowness). Pairs, isolated adults and groups were censused apart and brood size and age were systematically recorded. Duckling age was assessed according to Fournier and Cordonnier (1982).

The field work had to rely on different observers across regions and usually from year to year, but all weekly counts in each region for a given year was done by a same observer.

\section{> DATA ANALYSIS}

\section{Pair density}

Pair density (PD) is a major variable for investigating the variations in carrying capacity of duck habitat. Dzubin (1969) acknowledged that estimates taken from direct ground counts should be considered as approximations of absolute breeding pair number per unit area, subject to many vagaries of species behaviour, visibility, mobility and seasonal nesting chronology. Rotella et al. (1995) concluded nevertheless that for many research and monitoring applications, the level of error may be inconsequential and that methods currently used in North America, which are more easily applied than the mark-resight estimator, may be adequate. These methods rely on the fact that breeding pairs restrict their activity during the pre-nesting, laying and early incubation periods (Sowls, 1955). In North America, studied ponds are visited four times during a 7 to 10-day period between May 5 and May 25. If a pair or lone drake is observed on or near the same pond on three out of the four counts, a breeding pair of that species is assigned to that area. This method may be discarded for diving ducks in regions where they tend to aggregate on large and deep ponds, and to fly to surrounding smaller ponds ( $<0.3 \mathrm{ha}$ ) for nesting, feeding and loafing; in this case, diver populations are censused by searching for over-water nests (Dzubin, 1969). But considering pond sizes in our study regions, we assessed similarly dabbling duck and diving duck pair numbers per pond, during the pre-nesting and early incubation periods, i.e. between April 15 and May 25 (at least 5 visits) so as to include the peak of the Mallard laying period in the second half of April. Unlike in North America, pairs and isolated adults were systematically censused apart in each weekly counting and the large groups of males, females or both sexes were normally not considered for assessing pair number per pond. From each weekly count in each pond, we added to observed pairs, either lone females, or males alone and in small groups $(<5)$, to retain the highest of both additions. Pair number per pond corresponded to the highest number recorded at least three times across the study period (April 15-May 25). Of course, we cannot ascertain that pairs assigned by this method to a given pond eventually nested there.

Defining comparative indices of pair number per unit area was complicated by the strong interaction between pond surface and duck abundance. In this study, a clear relationship was constantly observed: positive between duck pair number per pond and pond surface area ( $F>90, P<0.001$ ), negative between pair density (i.e. pair number divided by surface area) and pond surface area $(F>10, P \leqslant 0.001)$. To efficiently offset this effect $(F<0.5, P \geqslant 0.49)$, pair number was divided by the square root of surface area. PD here was the annual mean value in each sample.

\section{Index of nesting productivity}

This annual index (NP) corresponded in each study region to the ratio of brood number to pair number at the scale of the pond sample. Pair number was the sum of pairs in each pond. Because week by week brood movements possibly occur between neighbouring ponds, we considered only $\leqslant 2$ week-old broods to limit the risk of double counting. Brood number was the sum of all $\leqslant 1$ week old broods recorded at different dates throughout the sample and 
of 2 week-old broods provided that no $\leqslant 1$ week old broods of same or bigger size were observed in the same pond or in surrounding ones (within $1 \mathrm{~km}$ range) in the preceding weekly count. Note that this method provided no information about nest location but, in both of the predominant species, strong correlations were observed yearly at pond level between brood number and pair number (Pochard: $F>9, P \leqslant 0.003$; Mallard: $F>25, P<0.001$ ).

\section{Duckling loss in early stages of growth}

In French fishponds, duck brood size mainly decreases during the first 3 weeks after hatch (Broyer, 2002). Duckling losses in pond samples (DL) were therefore estimated as the difference (in percent) between 1-week-old duckling number and 3-week-old duckling number: [ $(n \times$ mean size 1-week-old broods) $-(n \times$ mean size 3 -week-old broods $)] /(n \times$ mean size 1 -week-old broods). To limit the possible error induced by present but undetected broods, 1-week-old brood number was considered as being equal to 1-week-old +2 -week-old observed for the first time, and 3-week-old brood number was equal to 3-week-old + 4-week-old not observed at the age of 3 weeks. This method assumed that any ingress of brood into the pond sample was counterbalanced by a similar egress of the same number out of the studied water bodies.

\section{Brood size}

Brood size (BS) was assessed only for $\leqslant 1$ week old broods. The risk of mortality for ducklings being usually greatest during the first ten days (Korschgen et al., 1996; Orthmeyer and Ball, 1990), BS probably differed from clutch size.

\section{RESULTS}

\section{> OBSERVED CHANGES IN FISH FARMING MANAGEMENT}

In Forez, all study ponds were exploited for fish farming in 1998, but $32.5 \%$ were virtually abandoned in 2014 and mainly devoted to waterfowl hunting. In 2014, only 40\% were harvested annually. This result is in line with the general decline of fish farming in this region. In Brenne in $1999-2000,71.9 \%$ of study ponds were fertilized annually and $45.6 \%$ were limed. In 2013, $24.5 \%$ only remained annually fertilized and $13.2 \%$ limed. Fish-farmers however maintained artificial carp feeding, which was implemented in $66.7 \%$ of the ponds in 1999-2000 and $62.3 \%$ in 2013. For that reason probably, fish production did not collapse: $294.5 \pm 157.5 \mathrm{~kg} \cdot \mathrm{ha}^{-1}$ in $1999,242.5 \pm 130.8 \mathrm{~kg} \cdot \mathrm{ha}^{-1}$ in 2013 , i.e. a mere $17.7 \%$ decrease. We may expect that decreasing fertilization with still high fish biomass density would be detrimental to duck breeding in Brenne.

\section{> PAIR DENSITY}

Our results showed unequivocal PD increase in Forez fishponds, gradually doubling throughout the study period, in the Pochard $(F=12.460, P=0.003)$ as well as in the Mallard $(F=10.113, P=0.006)$. Such a striking trend was specific to this region, with pair density remaining virtually stable in Dombes and in Brenne (Table I, Figure 2).

\section{> INDEX OF NESTING PRODUCTIVITY (BROOD: PAIR RATIO)}

The brood: pair ratio declined in Dombes and, more sharply, in Brenne while remaining stable in Forez (Table I, Figure 3). In Dombes, NP decreased in the Pochard $(F=4.395, P=0.05)$ and in the Mallard $(F=6.735, P=0.019)$, but in the Mallard only in Brenne $(F=8.912, P=0.012)$. 


\section{Table I}

Linear regressions describing the inter-annual variation in indices of duck pair density (PD), nesting productivity (NP), brood size (BS) and duckling losses (DL), in Dombes (1994-2012), Forez (1992-2012) and Brenne (1999-2012). In bold: statistically significant trend with $P<0.05$.

\begin{tabular}{|l|c|c|c|}
\cline { 2 - 4 } \multicolumn{1}{c|}{} & Dombes & Forez & Brenne \\
\hline PD & $F=0.020, P=0.89$ & $\boldsymbol{F}=\mathbf{3 3 . 7 5}, \boldsymbol{P}=\mathbf{0 . 0 0 0}$ & $F=0.274, P=0.61$ \\
NP & $\boldsymbol{F}=\mathbf{4 . 4 9 9 ,} \boldsymbol{P}=\mathbf{0 . 0 4 9}$ & $F=0.361, P=0.56$ & $\boldsymbol{F}=\mathbf{8 . 6 6 3}, \boldsymbol{P}=\mathbf{0 . 0 1 3}$ \\
DL Pochard & $F=1.615, P=0.22$ & $F=0.000, P=0.99$ & $F=2.120, P=0.17$ \\
DL Mallard & $\boldsymbol{F}=\mathbf{4 , 5 6 0 ,} \boldsymbol{P}=\mathbf{0 . 0 4 8}$ & $F=1.645, P=0.218$ & $F=0.016, P=0.90$ \\
BS Pochard & $F=0.220, P=0.64$ & $F=0.923, P=0.35$ & $F=1.286, P=0.28$ \\
BS Mallard & $F=0.006, P=0.94$ & $\boldsymbol{F}=\mathbf{6 . 9 9 8 ,} \boldsymbol{P}=\mathbf{0 . 0 1 8}$ & $F=0.377, P=0.55$ \\
\hline
\end{tabular}

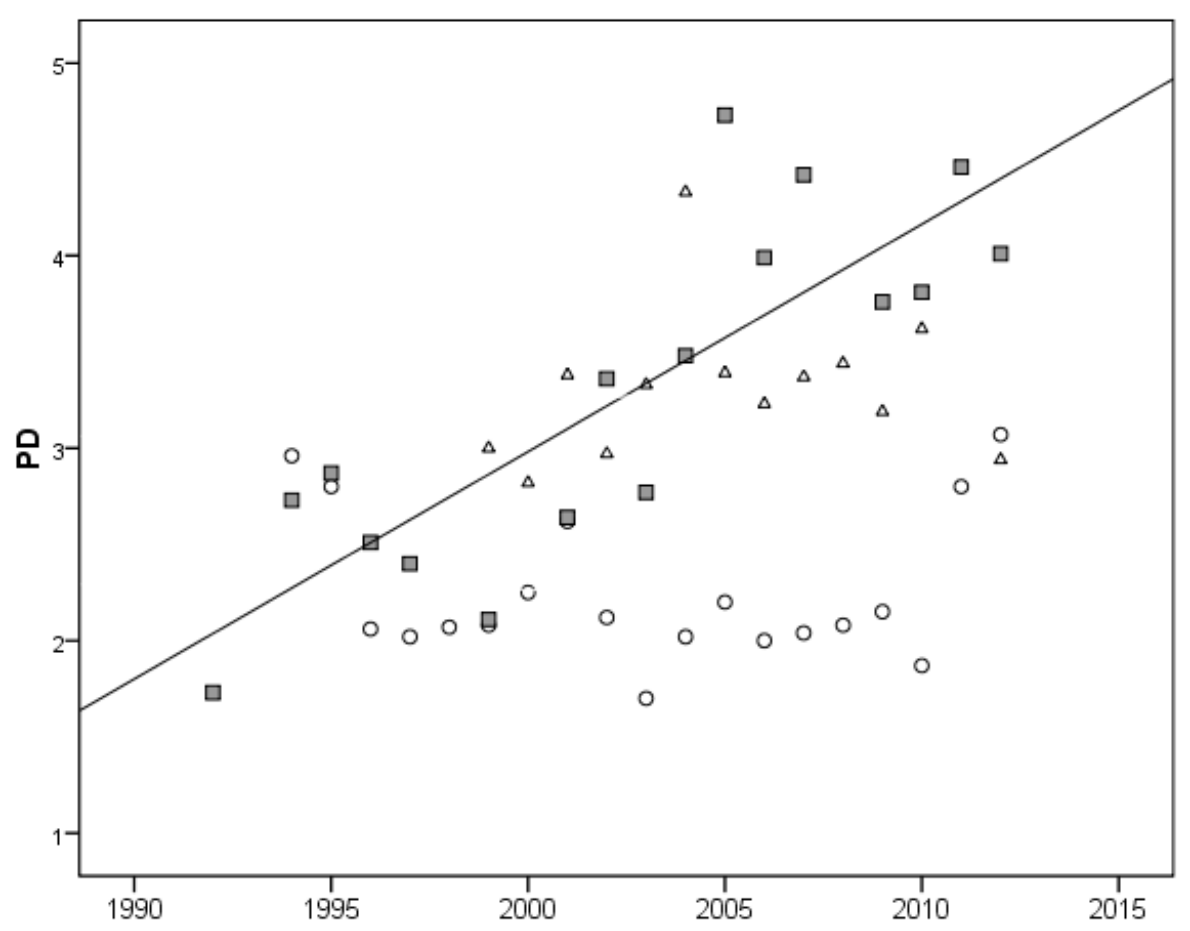

\section{Figure 2}

Variation in duck pair density $(P D=$ mean values of pair number divided by the square root of pond surface area) in pond samples of Dombes (circles), Forez (squares) and Brenne (triangles), with regression line for the Forez $(F=33.75, P<0.001)$. Sample size in Dombes: 80 ponds, in Forez: 60 ponds, in Brenne: 57 ponds.

\section{> DUCKLING LOSS}

No clear trend was observed for the Pochard in any region. In Forez however, interannual variations were much larger after 2000 (Table I, Figure 4). In the Mallard, DL strongly increased in Dombes (Table I, Figure 5).

\section{$>B R O O D$ SIZE}

Pochard brood size did not show a significant trend but, as for duckling loss, between-year variations were greater after 2000 in Forez (Table I, Figure 6). Mallard BS regularly decreased over the study period in Forez while remaining stable in Brenne and in Dombes (Table I, Figure 7). 


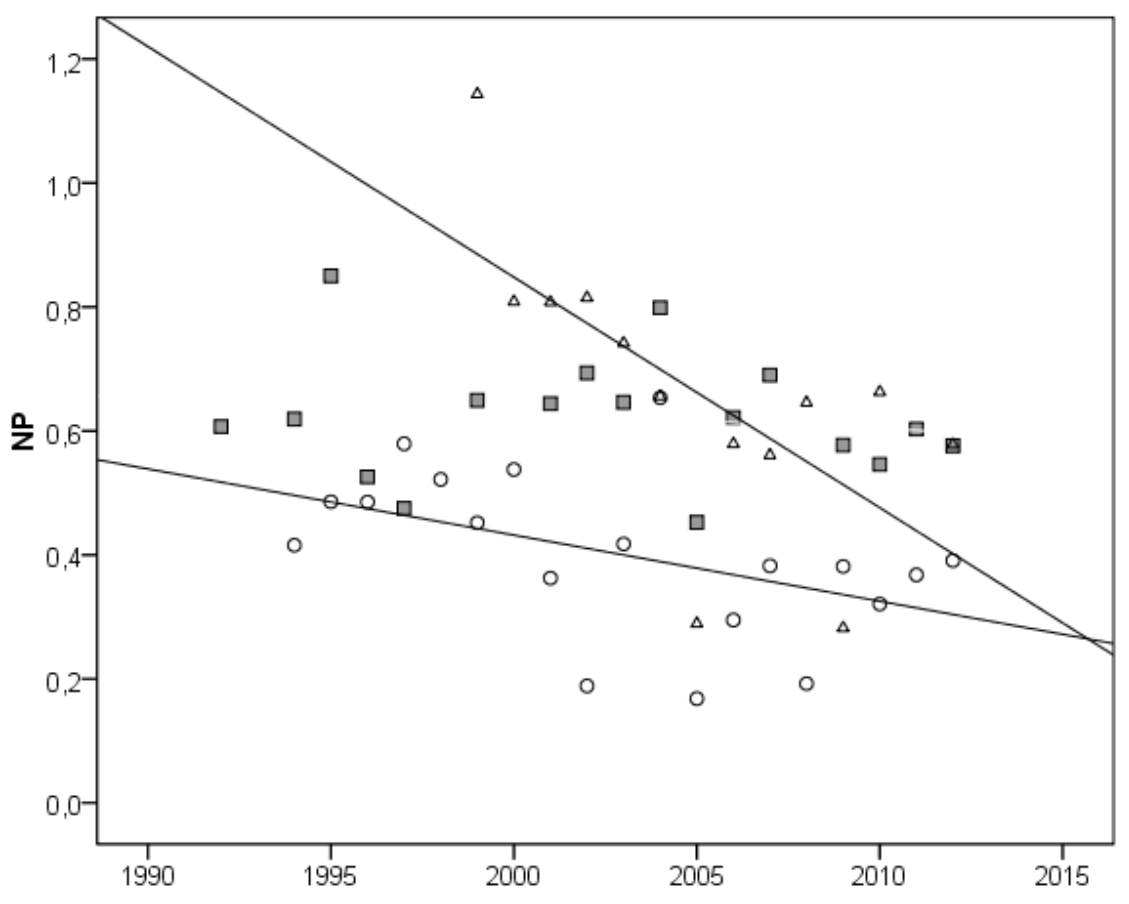

\section{Figure 3}

Variation in the brood: pair ratio (NP), in pond samples of Dombes (circles), Forez (squares) and Brenne (triangles), with regression line for Dombes $(F=4.499, P=0.049)$ and Brenne $(F=8.663, P=0.013)$. Sample size in Dombes: 80 ponds, in Forez: 60 ponds, in Brenne: 57 ponds.

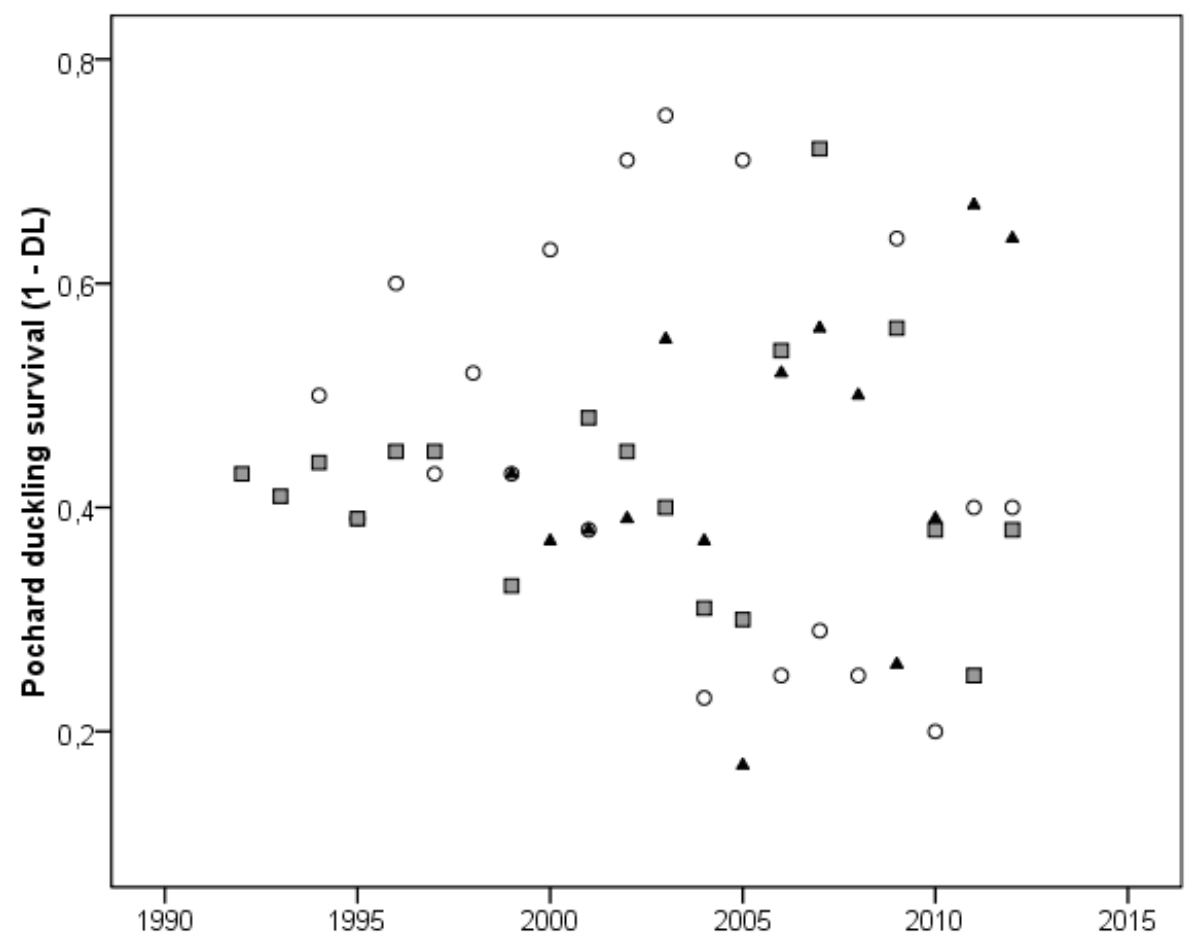

Figure 4

Variation in Pochard Aythya ferina duckling survival ( $D L=$ duckling losses), in pond samples of Dombes (circles), Forez (squares) and Brenne (triangles). Sample size in Dombes: 80 ponds, in Forez: 60 ponds, in Brenne: 57 ponds. 


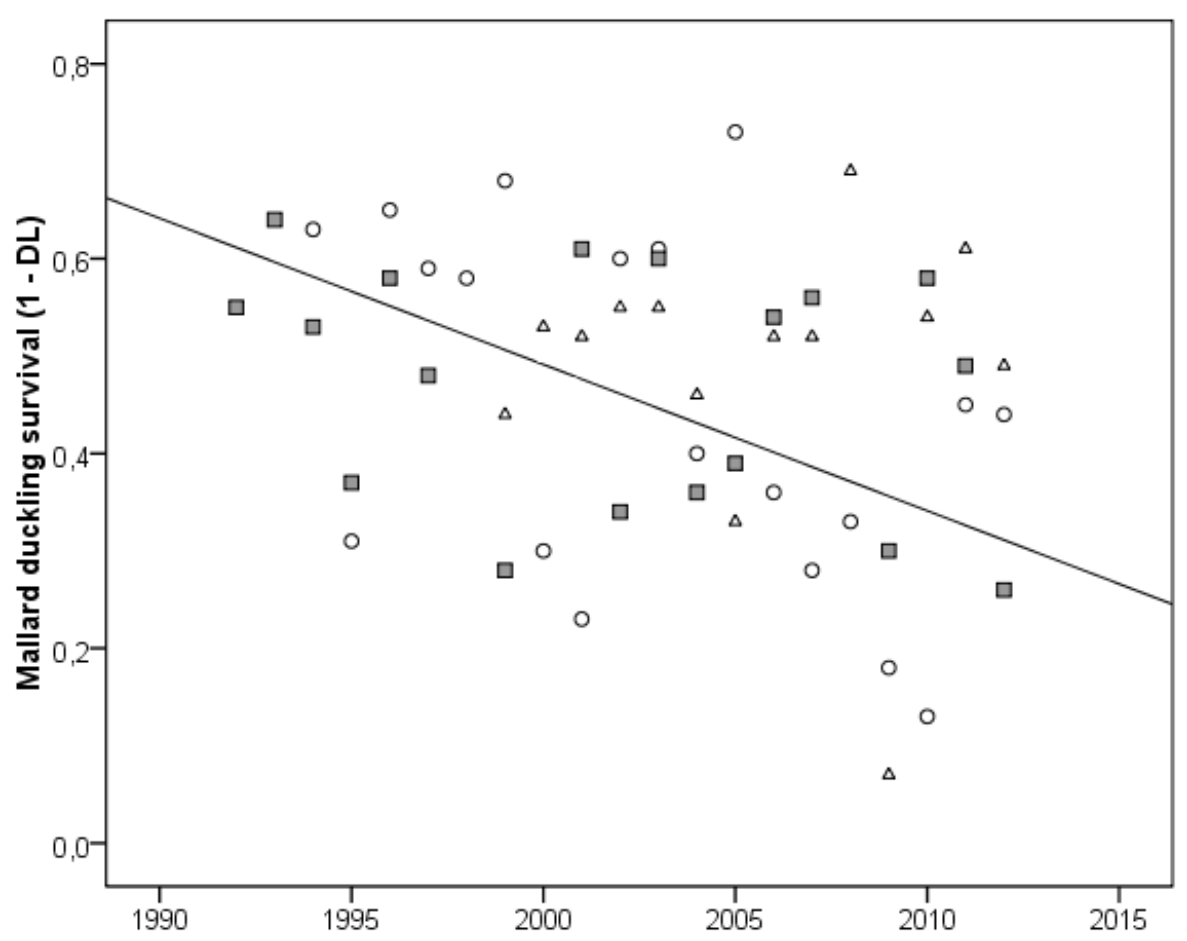

Figure 5

Variation in Mallard Anas platyrhynchos duckling survival ( $D L=$ duckling losses), in pond samples of Dombes (circles), Forez (squares) and Brenne (triangles), with regression line for the Dombes ( $F=4.560$, $P=$ 0.048). Sample size in Dombes: 80 ponds, in Forez: 60 ponds, in Brenne: 57 ponds.

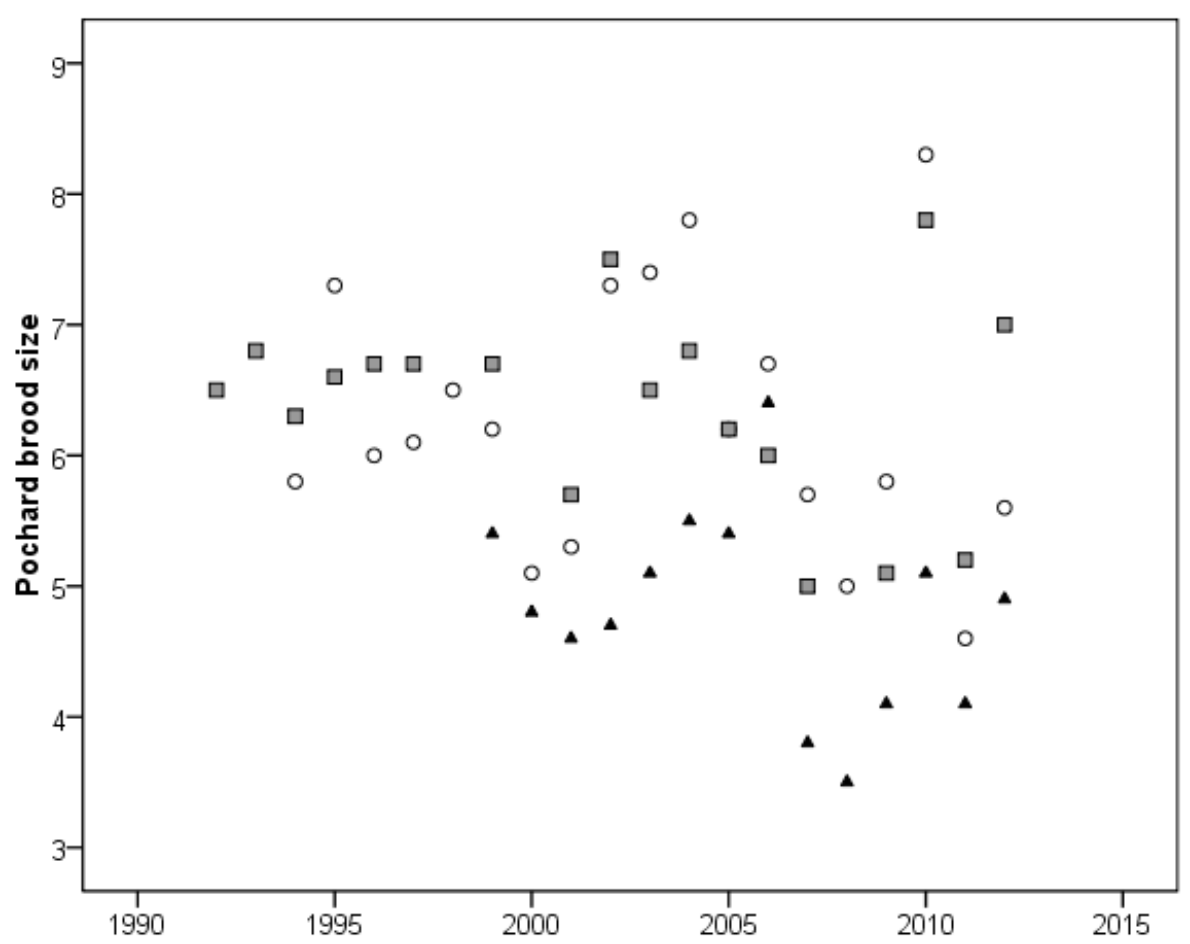

Figure 6

Variation in Pochard Aythya ferina brood size, in pond samples of Dombes (circles), Forez (squares) and Brenne (triangles). Sample size in Dombes: 80 ponds, in Forez: 60 ponds, in Brenne: 57 ponds. 


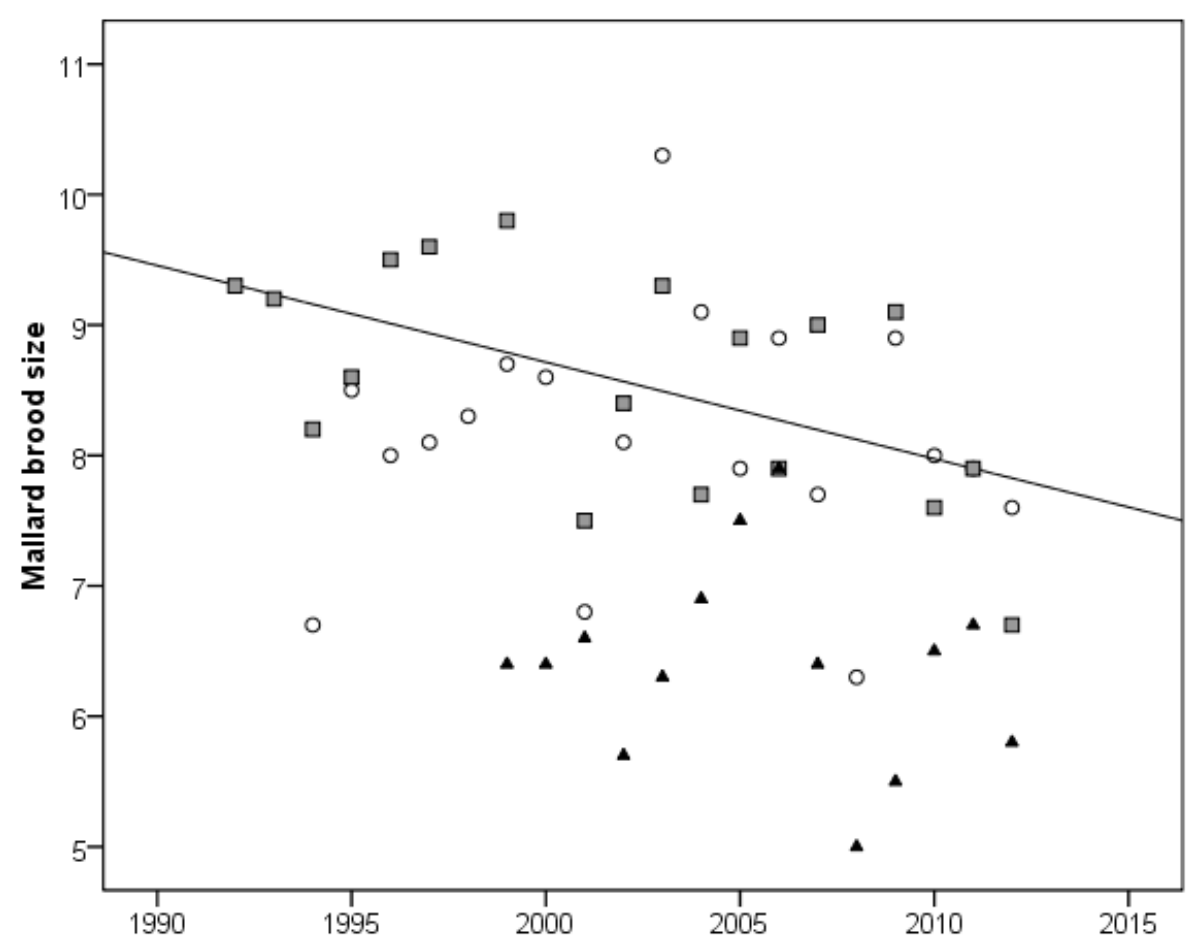

Figure 7

Variation in Mallard Anas platyrhynchos brood size, in pond samples of Dombes (circles), Forez (squares) and Brenne (triangles), with regression line for the Forez ( $F=6.998, P=0.018)$. Sample size in Dombes: 80 ponds, in Forez: 60 ponds, in Brenne: 57 ponds.

\section{DISCUSSION}

Very contrasting trends were observed in duck demography across three French fishpond regions simultaneously with changes in local fish farming. A substantial increase in pair density was observed in Forez. This increase was a specific regional trend since duck populations remained quite stable in the other two study regions. This two-fold increase in pair density had no obvious consequences on the brood: pair ratio or on duckling loss. The observed population increase was thus apparently not characterized by negative density dependent effects on nesting success or on duckling survival. However, a simultaneous decrease was recorded in Mallard brood size ( $\leqslant 1$ week old broods). The most plausible explanation for the observed changes is that, in a system with unchanged nutrient status (no fertilization, no artificial fish feeding), duck populations have benefited from lower competition with carps or lower impacts of carps on the aquatic ecosystem, but with possible density dependent consequences on Mallard brood size. Other hypothetical factors could have influenced duck population trends throughout the study period. But these factors: increasing impact of Coypu on aquatic vegetation or earlier mowing in hay fields potentially used by dabbling ducks as nesting places, would have been negative for ducks and cannot therefore explain the positive trend recorded in Forez.

Stable brood: pair ratio in Forez contrasted with a decrease recorded in Dombes and in Brenne, which could correspond either to a lower proportion of adults actually nesting, or to higher losses before or immediately after hatching. Such a negative trend could be hypothetically related to the arrival and the expansion of the Coypu, with correlative impacts on helophyte stands and reduction in available areas of nesting habitat (Curtet et al., 2008), thereby increasing the risk of clutch predation (Broyer, 2009). Under that hypothesis however, it would be difficult to explain the absence of negative effect on the brood: pair ratio in Forez despite the increased density of recorded pairs. In Brenne in 2000-2001, higher duck brood density was found in fertilized ponds, in which invertebrate biomass density was higher in macrophyte beds: $323 \pm 267 \mathrm{mg}$ dry weight/litre of macrophytes in fertilized ponds $(n=22)$ 
vs. $172 \pm 114$ in ponds without fertilization $(n=19)$ (Broyer and Curtet, 2011a). Moreover, Mallard and Pochard brood sizes were lower in Brenne than in the other French fishpond regions (Broyer, 2002 and this study). Since clutch size in ducks may vary in relation to available food supply (Ankney and Afton, 1988 ; Bengston, 1971; Esler and Grand, 1994; Coulson, 1999), it probably reflects intrinsic limits in pond carrying capacity in Brenne. Fertilization in aquatic ecosytems may lead to a shift from high coverage in macrophytes to phytoplankton dominance (Van Donk et al., 1993; Pokorny and Pechar, 2000; Jeppesen et al., 2000), which is detrimental to breeding ducks (Broyer and Curtet, 2010, 2011b). This shift was not observed in Brenne (Broyer and Curtet, 2011a). We suggest that the decreasing frequency of pond fertilization in Brenne could explain a lower nesting productivity.

In Dombes, the brood: pair ratio decreased and duckling loss increased in the Mallard; the brood: pair ratio also decreased in the Pochard. Our indices therefore did not reveal any positive variation in duck breeding success which could be attributed to local changes in fish farming.

Different regional patterns in duck demographic trends were described in parallel with recent changes in fish farming management. This enabled us to discard possible effects of some general causes such as climatic change. Duck population increase in Forez matched a significant decrease of fish biomass density in ponds. The hypothetical cause-effect relationship is in line with the positive consequences of fish absence or scarcity for duck breeding in lake ecosystems, reported in several studies (Parker, 1991; Desgranges and Gagnon, 1994; Mallory et al., 1994). In Brenne, Mallard nesting productivity declined in a pond sample where nitrogen inputs in the aquatic ecosystem and a probable correlative invertebrate availability for ducks, were substantially reduced. In the Mallard, the probability of producing eggs increases with female body condition (Cowardin et al., 1985). The proteins required for egg production are obtained by foraging on aquatic macro-invertebrates on the breeding areas (Krapu, 1981). Less frequent pond fertilization in Brenne is therefore a possible explanation for the observed decrease in the Mallard brood: pair ratio. In Dombes, lower fish biomass did not compensate for the long term consequences of agriculture intensification in pond watersheds (i.e. massive grassland habitat loss, expansion of silage and early mowing, transfer with runoff of herbicides into fishponds). Overall, we may however consider that our results support the hypothesis of a strong relationship between fish farming practices and pond carrying capacity for ducks. Population size or reproductive results in French fishpond complexes seem likely to vary according to an interaction between fish biomass density and the primary productivity of the aquatic ecosystem. This productivity may be artificially boosted by fertilizer inputs but with the risk of dramatic consequences on aquatic vegetation. Fishpond carrying capacity for ducks, which is the environment's maximal load, would probably decrease when carp biomass or when artificial fertilization exceed a certain limit above which the macrophytic vegetation cannot develop and survive.

\section{ACKNOWLEDGEMENTS}

The authors thank the following fieldworkers, in Dombes: MM or Mrs Benmergui, Chimenton, Claret-Tournier, Combrisson, Cotton, Cremades, Duez, Durand, Geneste, Journet, Lemoine, Mayeux, Naud, Nibaudeault, Prost, Ricoul, Sudraud, Verdier; in Forez: MM. or Mrs Courtois, Delayre, Dumas, Fournand, Fournel, Gélineau, Genes, Giffon, Lachal, Lefebvre, Meichel, Nicole, Ollier, Pluvier, Roullier, Silvestre, Tessier, Thouilleux, Toutin, Vassas, Wastin; in Brenne: MM or Mrs Berton, Darchis, Hérault, Huguet, Laroche, Paré.

We also thank C. Carter for the improvement of the English writing.

\section{REFERENCES}

Agreste, 2010. Poissons d'étangs. Enquête 2010. MEDDE, DPMA.

Albrecht T., Musil P. and Cepak J., 2000. Habitat selection of waterfowl broods on intensively managed fishponds in the Czech Republic. Sylvia, 36, 18. 
Ankney C.D. and Afton A.D., 1988. Bioenergetics of breeding Northern Shovelers: diet, nutrient reserves, clutch size and incubation. Condor, 90, 459-472.

Association pour le Développement de l'Aquaculture et de la Pêche Professionnelle en Rhône-Alpes (ADAPRA), 2011. Audit de la pisciculture d'étangs dans la Loire.

Bengston S.-A., 1971. Variations in clutch size in ducks in relation to the food supply. Ibis, 113, 523-526.

Bobbe S., 2010. Etude des impacts de la population de grands cormorans sur les activités piscicoles et les milieux qui en dépendent. ITAVI, Sciences-Po, $95 \mathrm{p}$.

Bouffard S.H. and Hanson M.A., 1997. Fish in waterfowl marshes: waterfowls managers' perspectives. Wildl. Soc. Bull., 25, 146-157.

Broyer J., 2000. La Dombes, espace d'équilibre ou simple substrat pour la culture céréalière ? Courr. Environ. INRA, 40, 63-65.

Broyer J., 2002. Résultats comparés de la reproduction des anatidés dans trois principales régions de nidification de France: la Dombes, la Brenne, le Forez. Alauda, 70, 377-386.

Broyer J., 2009. Compared distribution within a disturbed fishpond ecosystem of breeding ducks and bird species indicators of habitat quality. J. Ornithol., 150, 761-768.

Broyer J. and. Calenge C., 2010. Influence of fish-farming management on duck breeding in French fishponds systems. Hydrobiol., 637, 175-185.

Broyer J. and Curtet L., 2010. The influence of macrophyte beds on ducks breeding on fishponds of the Dombes region, France. Wildfowl, 60, 136-149.

Broyer J. and Curtet L., 2011a. The influence of fertilization on duck breeding in extensively managed fishponds of the Brenne, Central France. In: Ponds, Formation, characteristics and uses. Nova Science Publ., New York.

Broyer J. and Curtet L., 2011b. The influence of fish farming intensification on taxonomic richness and biomass density of macrophyte-dwelling invertebrates in French fishponds. Knowl. Manag. Aquat. Ecosyst., 400, 10.

Conseil Général de l'Ain, 2013. Filière piscicole de l'Ain. Livre blanc 2013-2015, 90 p.

Coulson J.C., 1999. Variation in clutch size in the Common Eider: a study based on 41 breeding seasons on Coquet Island, Northumberland, England. Waterbirds, 23, 225-207.

Cowardin L.M., Gilmer D.S. and Shaiffer C.W., 1985. Mallard recruitment in the agricultural environment of North Dakota. Wildl. Monogr., 92, 1-37.

Crivelli A.J., 1983. The destruction of aquatic vegetation by carps. Hydrobiol., 106, 37-41.

Curtet L., Benmergui M. and Broyer J., 2008. Le dispositif exclos/témoin, un outil pour évaluer l'efficacité de la régulation du ragondin. Faune Sauvage, 280, 16-23.

Desgranges J.L. and Gagnon C., 1994. Duckling response to changes in trophic web of acidified lakes. Hydrobiol., 280, 207-221.

Dzubin A., 1969. Assessing breeding populations of ducks by ground counts. Saskatoon Wetlands Seminar. Can. Wildl. Serv. Rep. Ser., 6, 178-237.

Esler D. and Grand J.B., 1994. The role of nutrient reserves in clutch formation by females northern pintails in subarctic Alaska. Condor, 96, 422-432.

Fournier J.Y., Cordonnier P., 1982. Critères de détermination de l'âge du Canard colvert de la naissance à 9 semaines. Bull. Mens. ONC, 63 suppl. $n^{\circ} 10$.

Haas K., Kohler S., Diehl S., Köhler P., Dietrich S., Höller S., Jaensch A., Niedermaier M., and Vilsmeier J., 2007. Influence of fish on habitat choice of water birds: a whole system experiment. Ecology, 88, 2915-2925.

Jeppesen E., Jensen J.P., Søndergaard M., Lauridsen T. and Landkildehus F., 2000. Trophic structure, species richness and biodiversity in Danish lakes: changes along a phosphorus gradient. Freshwat. Biol., 45, 201-218.

Korschgen C.E., Kenow K.P., Green W.L., Johnson D.H., Samuel M.D. and Sileo L., 1996. Survival of radio marked canvasback ducklings in northwestern Minnesota. J. Wildl. Manage., 60, 120-132.

Kozulin A., Ostrovski O., Tanneberger F., Pareiko O. and Yrko V., 2002. Waterbirds of large fishponds of Belarus and Lithuania. OMPO and Lithuanian Institute of Ecology of Vilnius, $127 \mathrm{p}$.

Krapu G., 1981. The role of nutrient reserves in Mallard reproduction. The Auk, 98, 29-38. 
Lilie R.A. and Evrard J.O., 1994. Influence of macroinvertebrates and macrophytes on waterfowl utilization of wetlands in the Prairies Pothole Region of north-western Wisconsin. Hydrobiol., 279/280, 235-246.

Mallory M.L., McNicol D.K. and Weatherhead P.J., 1994. Habitat quality and reproductive effort of Common goldeneyes nesting near Sudbury, Canada. J. Wildl. Manage., 58, 552-560.

Meijer M.-L., Lammens E.H.R.R., Raat A.J.P., Grimm M.P. and Hosper H., 1990. Impact of Cyprinids on Zooplankton and Algae in ten drainable ponds. Hydrobiol., 191, 275-284.

Orthmeyer D.L. and Ball I.J., 1990. Survival of mallard broods on Benton Lake National. J. Wildl. Manage., 54, 62-66.

Parker G.R., 1991. Survival of juvenile American Black ducks on a managed wetland in New Brunswick. J. Wildl. Manage., 55, 466-470.

Pokorny J. and Pechar L., 2000. Development of fishpond ecosystems in the Czech Republic: role of management and nutrient input (Limnological review). Sylvia, 36, 8-14.

Pykal J. and Janda J., 1994. Početnost vodních ptáků na jihočeských rybnících ve vztahu k rybničnímu hospodaření. Sylvia, 30, 3-11.

Robin J., 1999. Dynamique saisonnière du phytoplankton en étang de pisciculture de la plaine du Forez (Loire). Essai de contrôle des cyanobactéries, Thèse Université Lyon 1.

Rotella J.J., Devries J.H. and Howerter D.W., 1995. Evaluation of methods for estimating density of breeding female mallards. J. Field Ornithol., 66, 391-399.

Sowls L.K., 1955. Prairie Ducks, a study of their behavior, ecology and management. Harrisburg, Stackpole, $193 \mathrm{p}$.

Tournier H., 1990. Dynamique des populations de Canard colvert et de Fuligule milouin en Dombes et Forez. In «Actes du $17^{\mathrm{e}}$ colloque francophone d'ornithologie. Paris, 4-5 mars 1989 ». Alauda, 58, 46-47.

Van Donk E., Gulati R.D., ledema A. and Meulemans J.T., 1993. Macrophyte-related shifts in the nitrogen and phosphorus contents of the different trophic levels in a biomanipulated shallow lake. Hydrobiol., 251, 19-26.

Cite this article as: J. Broyer, F. Bourguemestre, G. Chavas and R. Chazal, 2015. Temporal variation in pond use and breeding success for ducks in French fishpond regions: on possible consequences of a decline in fish farming. Knowl. Manag. Aquat. Ecosyst., 416, 31. 